\title{
Urban acupuncture treatment: Implementing communication tools with youth in Ljubljana suburbs
}

\begin{abstract}
Urban acupuncture actions are small-scale, bottom-up projects that foster community building. The approach provides an alternative to investor urbanism and motivates residents of neglected neighbourhoods to engage in place-making. The playground in Ljubljana's suburb of Zalog is a perfect example of an intervention that converted a neglected site into a main meeting point of the neighbourhood. The needs of youngsters were inquired about and considered; they became active partners in the transformation of public space. Urban acupuncture is a valuable tool for place-making in locations where market forces overshadow the residents' ability to make decisions about their own right to the city.
\end{abstract}

Keywords: urban acupuncture, place-making, investor urbanism, neighbourhoods, participation

\section{Introduction}

In the suburbs of Central European cities we are witness to a lack of activities available to youngsters in spite of the fact that public spaces have been reclaimed for mixed use. The capacity of young people to participate in the public life of their neighbourhood is diminishing. New forms of social structures and relationships among city dwellers have produced an unequal distribution of political power, which is not indicative of a promising future for European cities. Smith (2002) argues that gentrification has become a global urban strategy, influencing local urban environments around the world. Global capital accumulates in urban centres and accelerates the speed and scale of gentrification in large cities. In contrast to large-scale investment projects, urban acupuncture is a small-scale practice applied in micro urban environments, intended to engage local residents in the creation of their public space. It is a strategy for approaching urban renewal or development projects that acknowledges the needs of locals and other stakeholders and puts an emphasis on creating shared common spaces, accessible to the local population. Application of urban acupuncture includes research into local residents' needs and consideration of their perspectives in the planning process. Targeted actions are then carried out to change public space and improve the residents' quality of life. This paper presents an example of urban acupuncture, implemented in the Zalog suburb of Ljubljana which was specifically articulated to meet the needs of youngsters.

A lack of communication among stakeholders in urban environment can cause a disconnection between suburbs and the city centre. Marginalized suburban neighbourhoods become abandoned, vandalized, and neglected, lacking all appropriate programmes. Neglect is connected with unmitigated urban sprawl. Investor urbanism mode of operation is currently one of the most prominent reasons for weak local communities. Direct implementation of investment capital interests leaves little room for communication. Urban acupuncture is a method of intervention and resistance that can disrupt and influence profit-driven investor urbanism in action and, through the 
participation of the public, tip the scale in favour of public interest. It influences community building by inspiring residents to acknowledge common ownership of a particular public space and use it to express and reinforce their local identity. Insisting on discussion and creating concrete urban interventions in neglected spaces is an important aspect of community building.

The focus in Ljubljana was on youth, defined here as the generational group between 8 and 25 years old. The use of new communication tools and methods made distribution within a wider group of users easy. Different new methods were used to involve the youth in collaboration as the approaches previously used to attract their participation had failed.

In a top-down setting of the power city, contents are dictated by investors or developers, and urban dwellers are not considered important as the capital reshapes the city in pursuit of profit. Investor urbanism represents a form of spatial development in which investors and/or politicians make decisions about a city's development without giving residents or other community representatives any opportunity to provide their input. The only objective is to maximize profit through the implementation of corporate design that invariably affects the community. Investor urbanism has been especially prevalent in countries undergoing transition between different political regimes, where urban development is subject to corruption and real estate manipulation.

The rise of investor urbanism, as described by Lefebvre and Harvey in the 1970s, laid the fundaments for the expansion of the capitalist system. According to Lefebvre, the development of the contemporary city is a product of the capitalist system, where the state uses space for social control (Patel, 2015). Investor urbanism is part of capital accumulation and class relations. As the capital accumulation strategies moved away from productive sectors in the late 1970s and 1980s, the production of built environment emerged as a viable alternative to mop up surplus capital. Governments in cooperation with the private sector passed business-friendly laws and regulations, turning profitdriven urbanism into the main site of capital accumulation. This sort of top-down projects usually results in privatization of urban commons and disregard for public interest in favour of private gains.

According to Harvey (2008), since the 1970s the solution to the issue of surplus capital has been solved by urbanization, absorbing capital by restructuring, renovation, expansion, and speculation. Harvey (2008) argues that the city and the real estate market are produced by capital accumulation governing present-day economy. Vives Miro (2010) describes how "since the nineties, the expansion of neoliberalism has involved the entrepreneurial turn of local governments, by playing a new role in the urban governance. Local governments, in conjunction with private agents and urban elites, have turned into promoters of developments, producing the city based on competitive logics, in order to scale positions in the global urban hierarchy. In this sense, gentrification policies have been one of the main urban strategies that have driven cities towards success in the global market." The rise of investor urbanism causes the adaption of space to gentrification policies, as already described by Florida (2003) in The rise of the creative class. His theory is based on the notion that attracting creative people to a city will strengthen its economic performance. Riegler (2013) states that, instead, gentrification is sugar coated in terms like urban renewal or urban regeneration. Policy makers can hide behind Florida's theory and promote an environment in neighbourhoods favourable to the young urban creative elite but completely bypassing all consideration of the current residents' 
needs. In a recent podcast (Chamberlain, 2017) Florida expresses a concern, discussed in his new book, of a new urban crisis concerning the growing poverty in the suburbs. The reason for this crisis lies in the fact that people who move to the suburbs are nowadays often the disadvantaged that have been pushed out from the city centre. This is a new facet of the growing spatial inequality. The new urban crisis is a term describing the growing spatial inequality and a simultaneous decline of the middle class in city neighbourhoods.

An alternative possible approach to improvement of a certain neighbourhood, city or region involves the process of place-making where dwellers become involved in all aspects of projects that reinvent public space as the centre of their community (White, 2001). In a collaborative process public space can be shaped in such a way as to maximize its shared value. It is not the urban design, its products or authors, but the use of specific action patterns to create spatial, cultural, and social identities that define a place. However, when place-making is shaping public spaces through a participatory process, it is important to increase the values attached to those spaces by citizens. "Keeping the high quality of places over time can be a real challenge, especially in times of austerity. Placekeeping offers some solutions for local authorities to face these challenges" (Schmoch, 2017).

To understand fully the difference between the top-down approaches and urban acupuncture, we shall examine concrete examples from two former Yugoslavian cities: Koper and Belgrade. Both cases demonstrate how city dwellers cannot participate in topdown projects. Czepczyński (2008) states that socialistic urban typologies and strategies defined the space of the former communist cities in central Europe in a way that is difficult to react to. In Koper, Slovenia, a project was started in 2007 when municipal councillors approved the construction of a building that would house an Olympic centre, including a swimming pool, wellness and conference centres, offices, and municipal administration, in a central location near the historical city centre. More than ten years later the construction remains unfinished. When the construction company went bankrupt, work in this prominent location was discontinued, and the unfinished shell still stands there after a decade of decay (Figure 1).

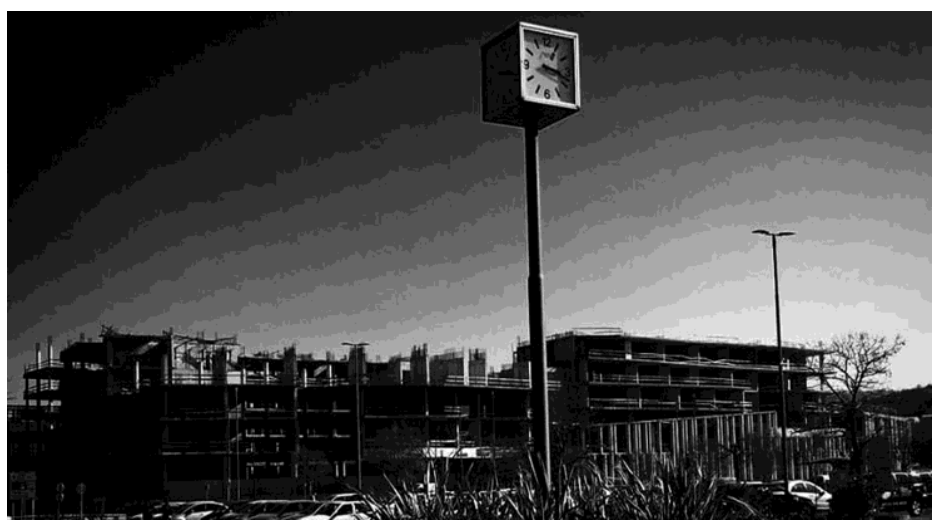

Figure 1: The unfinished construction at the entrance of the historical city of Koper (photo: Boštjan Bugarič). 


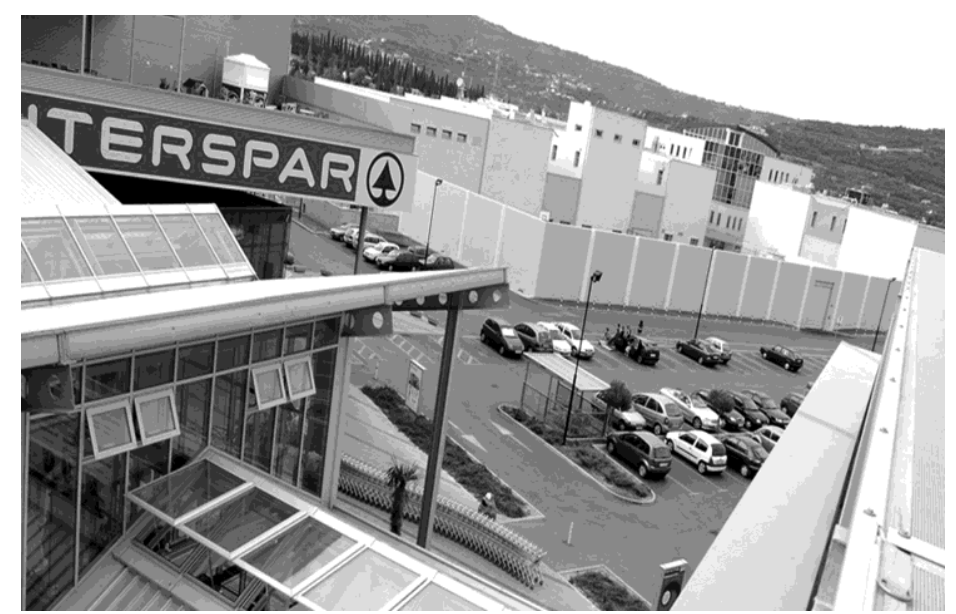

Figure 2: Shopping mall in Koper shares its parking lot with the city prison (photo: Domen Grögl).

As a case in point, the Koper municipality councillors also approved the construction of the shopping mall right next to the city prison, which is isolated from its surroundings. The prison planed in the 1980s thus shares a parking lot with a commercial area constructed after the lot was sold to private investors in the 2000s (Figure 2). In Koper, inclusive design of public spaces that takes the needs of residents' into account is severely limited and municipality politics plays the decisive role in urban planning. The public is disempowered and does not express disagreement with the city's investments in public space or architecture. A public primary school, for example, was equipped with a plaque that celebrates the political victory of the mayor (Bugarič, 2010). There has not been any public reaction to the plaque since the school was built (Figure 3).

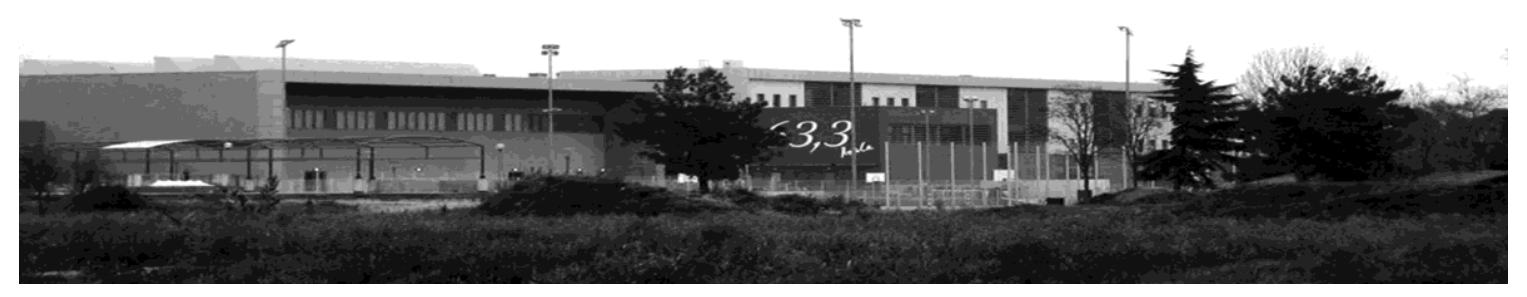

Figure 3: The inscription "63.3 hvala" on the facade of the Koper primary school refers to the support (in percentage points) that the mayor's side received in the referendum on the construction of the school (photo: Boštjan Bugarič).

A very similar process on a much larger scale is happening in Belgrade, where an urban design for Waterfront was proposed during the 2012 municipal election. During the 2014 parliamentary election cycle, the project was promoted as a way to improve city life. However, the public was not informed about the fact that the Waterfront project was subject to foreign capital investment and primarily a profit-making venture, not a city improvement scheme. The project includes plans for the construction of 6,178 housing units that will bring anticipated revenue of approximately EUR 2.5 billion. 
Vilenica, Sekulić, and Čukić (2015: 5) describe how "urban planners started looking at the space owned by the city not as a resource and a control mechanism to sustain equality in future development, but as a source of fast profit." In 1985 the planning legislation was modified to simplify granting approval to profitable development projects. In this way urban planners catered to investors' wishes. Investor urbanism is taking place on different scales. The sites of urban renewals are presented as future attractive locations that promise to attract further investments in line with the Bilbao effect. Namely, in Bilbao, popularity and financial growth were brought to a rundown city area in economic decline with the construction of an architectural landmark, the Guggenheim Museum.

The reaction of civil society to large-scale projects is protest. In Belgrade, 20,000 people gathered in the streets. In Koper, people express disagreement with discussions in daily and social media, through art, and activist actions such as VIVAT LOGGIA! The two examples show a similar reaction of the local population to a top-down approach. We employed a bottom-up approach and small-scale urbanism, following the methodology described below.

\section{Methodology}

\subsection{Cultural Acupuncture Treatment for Suburbs project}

European suburbia develops in borderless landscapes on the outskirts of historical centres. Kádár (2012) outlines how neighbourhoods are considered suburban in their given socio-cultural environments. Different extra-urban typologies, such as favelas in South America, high-rise housing estates in Russia and Hong Kong, and the sprawl of detached houses for the upper classes in the United States are becoming new ways of suburban living for the lower social classes. Central European cities annexed suburban villages during the 20th century and started the process of suburbanization, which "lead to the formation of the first upper-class suburbs, where the rich escaped to from the centres and their noise, pollution and the more and more visible working class. These first suburban areas were originally characterized by mono-functional living environments" (Kádár, 2012). But a long-lasting mono-functionality of these areas and the absence of diversity produced deserted suburbs lacking any identity.

In the scope of the project Cultural Acupuncture Treatment for Suburbs (Culburb), financed by the Education and Culture DG - Culture Programme with the support of the European Commission, six cities were involved in the implementation of urban acupuncture interventions. The project was organized and coordinated by the main coordinator, the Centre for Central European Architecture (CCEA) in Prague and coorganized in Vienna, Bratislava, Budapest, Warsaw and Ljubljana. Between 2010 and 2013, a suburb area in each of these cities was identified and targeted with urban acupuncture strategies by local coordinators. The selected locations were associated with problems such as economic hardship/shortage of jobs, commuter areas with people commuting to the city centres for work (byproduct of mono-functional environment), tensions with immigrants, and growing anti-immigrant and nationalist sentiments that disrupt the harmony in local communities.

Growing anti-immigrant and nationalist sentiment is the most common cause of disruption of the harmony of suburban communities with their development. This 
problem was tackled in suburbs, including Ljubljana. Zalog is located at the east end of Ljubljana. While part of Yugoslavia, the area experienced a high rate of immigration from other parts of the common state. In consequence, the present-day generation of youngsters has a very diverse mix of cultural backgrounds. Slovene population is in minority and it has proven difficult to integrate youngsters into the city. Instead, the youth have developed their own urban identity. Zalog is located outside the Ljubljana ring road, which makes the area feel remote in comparison to other parts of the city. Due to the collapse of industry in the area, there is a serious shortage of jobs, so many people commute to work to the centre.

\subsection{Urban acupuncture: A case study in Zalog, Ljubljana}

Urban acupuncture fosters interactions among inhabitants of a neighbourhood to cultivate community life (Culburb, 2013). Gruber (2012) talks about urban acupuncture as "a set of actions based on an inductive reading and physiological understanding of an urban milieu. It identifies neuralgic points for focused interventions that promise to add-up to more than the mere sum of their parts. Only then urban plans might be implemented also bottom-up and incrementally through constant feed-back and re-adjustments." Urban acupuncture evokes the points of engagement of dwellers within a local community in small actions in micro urban environment, with the purpose of creating diversity of content in public spaces. Understanding the residents' needs is important; they must be studied before starting any urban acupuncture action. Implementation requires continuity; only continued feedback loops allow the necessary readjustments and building of trust within the community. The process of urban acupuncture implementation is structured in three phases: research, content observation, and action planning. Generally, an independent stakeholder (most often an NGO, in this case KUD C3) connects dwellers' (in this case the youngsters') perception of space with stakeholders. Over the course of a long-term process, a methodology based on solidarity values and collaboration was developed. The result of this process was renovation of a public space - the playground Plata - and the creation of a new meeting point of the neighbourhood (Figure 4).

The Zalog case study was focused on possible changes to the local landscape that could be made without large investments and without relying on the city government or municipality. The youngsters in Zalog were invited to communicate their needs in relation to their direct surroundings. The goal of the community building was to actively involve them in the shaping of their environment according to their needs in order to overcome their usual passive critical attitude towards public projects that often undervalue their creative potential. The reconstruction of the vandalized sports-field in Zalog emerged as an opportunity for a common project initiated directly by the local youth and affecting their immediate environment. This location had been a favourite meeting place for the young people of Zalog. It had a long-standing problem of weathered and destroyed benches, no access to drinking water, and inadequate lighting for playing sports in the evenings. Ljubljana, in particular its suburbs, is characterized by a relatively large population of second-generation immigrants, descendants of newcomers from other cultures (Džokić et al., 2011). Most of Zalog youth are descendants of immigrant parents from Serbia and Bosnia and Herzegovina. Urban acupuncture implementation was developed in the four-year process with participation of the Zalog community. The Zalog project involved the collaboration of the City Municipality of Ljubljana, the Youth Centre Zalog Čamac, a neighbourhood retirement home, the local community of Polje and the Zalog primary school, and was coordinated by the cultural association KUD C3. 


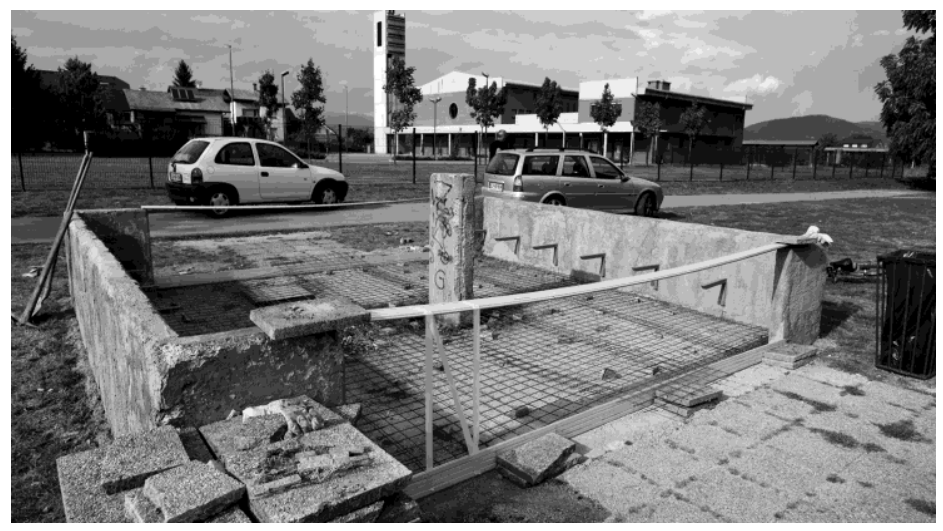

Figure 4: Action planning - renovation of the water well on the playground in Zalog as part of urban acupuncture process (photo: Domen Grögl).

\subsection{Project implementation}

Project implementation started in April 2010 and concluded in June 2013. KUD C3 association took on the leading role in the project, establishing communication between different parties. During the first phase - research -, KUD C3 initiated the partnership with a local stakeholder, the Zalog youth centre. Working together and gradually building trust yielded the basic concept of spatial development in the selected micro location (Plata playground), developed together with the city municipality and the local primary school. The renovation began in 2010 as a cooperation between the local youth and STEALTH.unlimited, brought together by KUD C3. In parallel, research started and continued throughout the implementation of the project; results were presented in a manual "This place exist only while we are here" (Džokić et al., 2011), an attempt towards creating effective means of involving young dwellers in the shape of their local built environment through diverse forms of engagement. On December 2011, the Building Public-ness festival was organized at the Museum of Modern Art in Ljubljana, at the Zalog primary school, and in several other public venues in Ljubljana. The event brought together architects, artists, designers, sociologists, cultural anthropologists, writers and curators. Through lectures, discussions, art interventions, exhibitions and workshops the participants encouraged the users of public space to start actively participating in the shaping of the environment they live in and to define its contents. Local and international institutions took part in the festival, including Centre for Central European Architecture (Prague, Czech Republic), University of Primorska (Koper, Slovenia), Academy of Design (Ljubljana, Slovenia), Academy of Fine Arts (Vienna, Austria), Parsons New School for Design (New York, USA), Association for Interdisciplinary and Intercultural Research (Zagreb, Croatia), Soho in Ottakring (Vienna, Austria), STEALTH.unlimited (Belgrade/Rotterdam, Serbia/The Netherlands), and Press to Exit Project Space (Skopje, FYROM).

The second phase focused on observations of space content. Youngsters communicated directly with experts at the youth centre and through social media channels. In this way the new content was defined according to the needs expressed by the target group, youngsters aged between 8 and 25 years. This phase took place during the first year of project implementation: KUD C3 established a connection with the youth centre in Zalog and other potential partners (City Municipality of Ljubljana, Local Community Polje, community centre, primary school, neighbourhood retirement home). KUD C3 conducted 
weekly meetings with different stakeholders and observed the needs of the young people over an extended period of time. Approximately 85 youth were involved in the project, as well as around 700 other people from the Zalog neighbourhood. The project was presented at other institutions and in other cities, among them the Parsons New School for Design in New York, the Faculty of Architecture in Belgrade, the Faculty of Architecture at the University of Ljubljana, the Deutsche Architektur Zentrum in Berlin, and the Architekturzentrum in Vienna. Observing the suburb content included feedback from social media, weekly interviews and hangouts at the playground, together with observations of the behaviour of youth gathering in the neighbourhood. Conclusions of our observations were distributed via social media, live conferences and different platforms, with the aim of attracting as many individuals as possible from the local community and informing the largest possible audience. Communication with youth and collaborative work with the Zalog community was always in the forefront of the working process. Distribution of information via social media assured that the youth were continuously involved in the process in real time.

The third phase focused on the development of the action plan. The regeneration of Zalog public space put its main focus on Plata, the local playground that was -at the start of the renovation-mainly used by local drug dealers. During the following five years, between 2011 and 2013, Plata was transformed into a community meeting spot. The playground was outfitted with lights, new benches and water fountains. In addition to young people, the space eventually attracted the elderly and mothers with children. They all played a role in transforming a once-vandalized area into a community gathering space. During this time, five artist residency programmes, coordinated by KUD C3, were conducted in the Zalog neighbourhood.

\section{Results}

The final results of urban acupuncture strategies implemented in the scope of Culburb were presented and evaluated at the Forum Acupuncture Conference in Ljubljana in April 2013. Six local coordinators and authors presented their projects from six different cities. In Zalog, urban acupuncture was used to engage local youth in the urban design of their neighbourhood.

The first urban acupuncture intervention was designed as a cooperation between youngsters and experts (Figure 5). Collaborating in the renovation of the abandoned playground by using recycled materials gave the local youth a larger sense of responsibility towards their environment. The young people's attitudes changed from those characteristic of a consumer society to those marking a society with a higher awareness of spatial, ethical and ecological aspects of their environment. During collaborative work carried out by the KUD C3 expert team and youth from Zalog in 2011 and 2012, the participating youngsters gained experience and knowledge on the subject of water recuperation. 


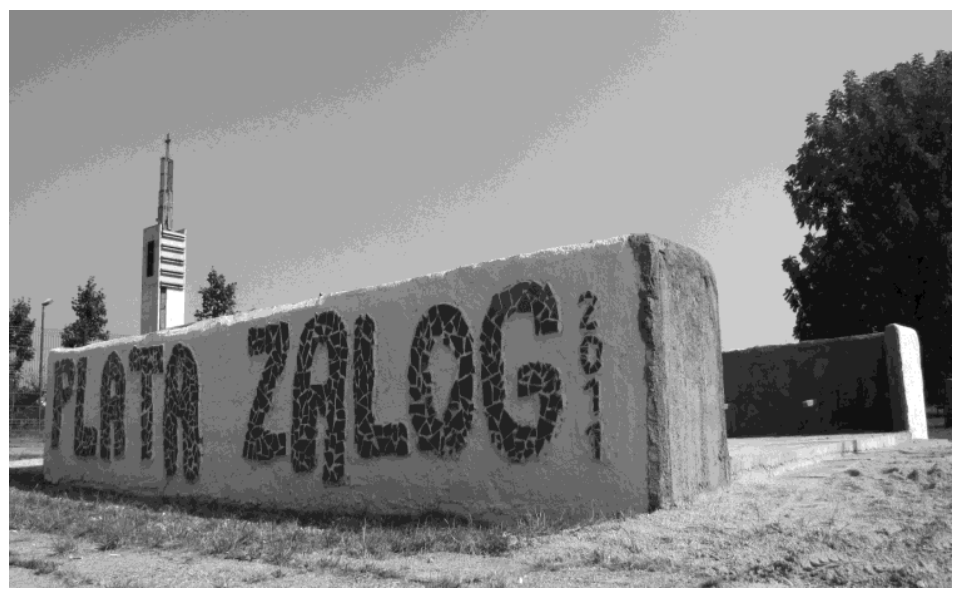

Figure 5: Urban Acupuncture - Down by the Water (photo: Domen Grögl).

The second urban acupuncture intervention was organized in December 2012 in collaboration with the architect Daniel Diaz Vidaurri from Mexico City (Figure 6). The organized workshop stimulated communication among the youth and encouraged them to design their ideal city, while simultaneously illustrating the way they perceive public space and the way they would like to break down the social and physical barriers between their neighbourhood and city areas they do not usually frequent.

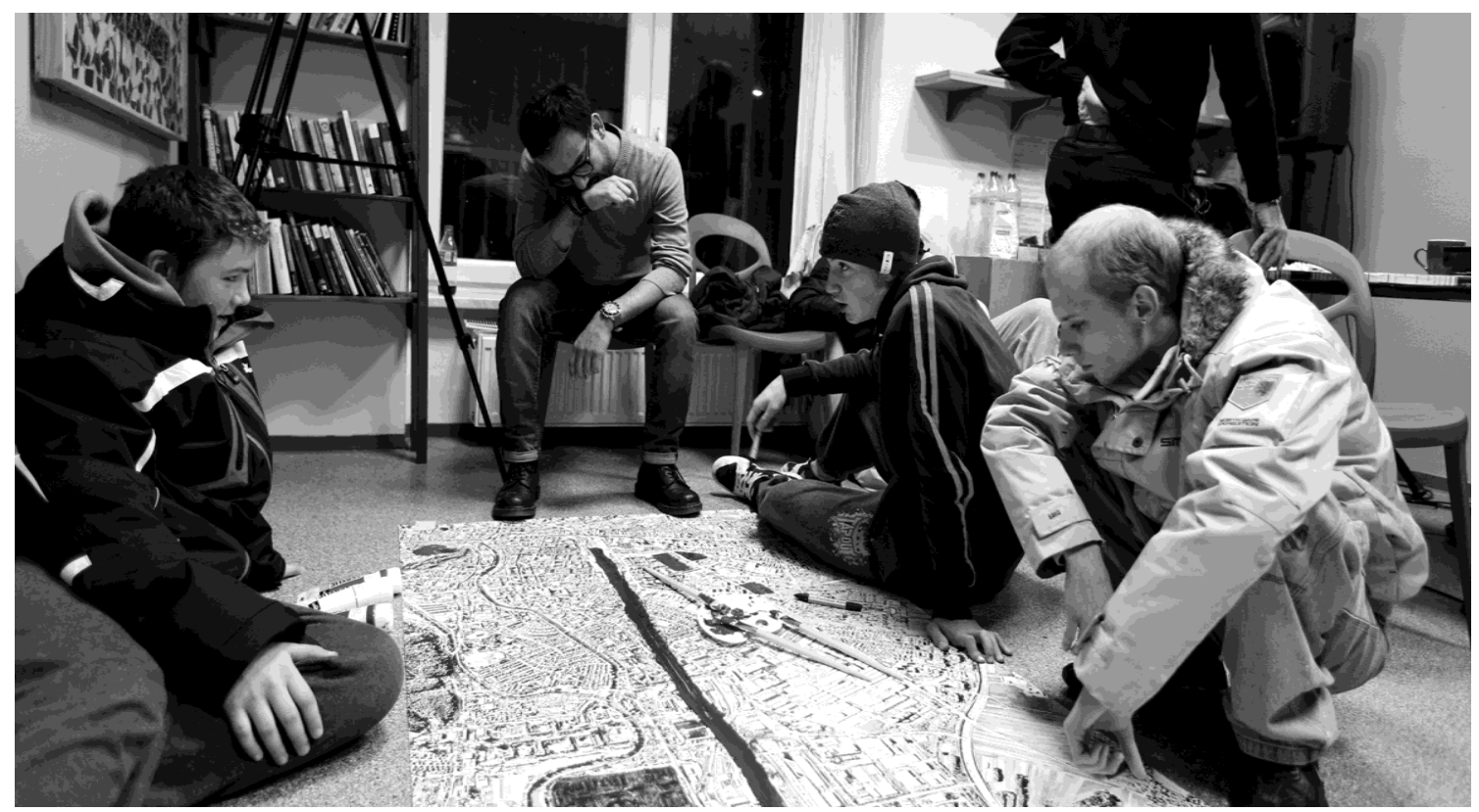

Figure 6: Urban Acupuncture - Design Your City (photo: Domen Grögl).

The third urban acupuncture intervention was carried out by artists Yane Calovski and Hristina Ivanoska with the creative collaboration of Anette Lundeby, designer and researcher from London. The artists engaged locals in a dialogue about their personal and collective expectations regarding public space through a collective performance entitled Stone Soup. The performance was a participatory action designed to draw out the youth's opinions on public space. This intervention was conducted in March 2012 at the Zalog primary school (Figure 7). 


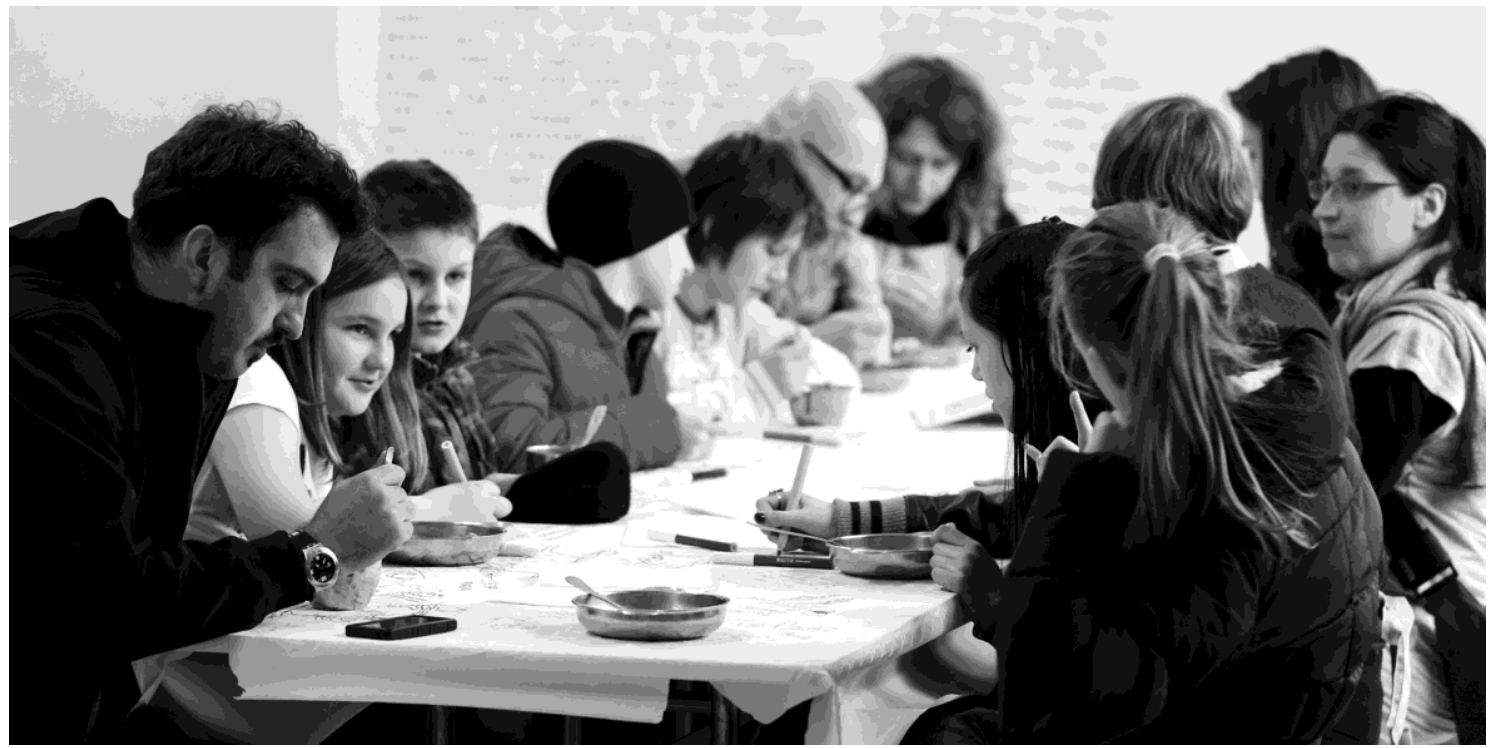

Figure 7: Urban Acupuncture - Conversation (photo: Domen Grögl).

The fourth urban acupuncture intervention was carried out between November 2012 and June 2013. The site of the intervention was a grass patch next to the playground where a meeting place for the local youngsters was constructed (Figure 8). The youth were partners in the creation process; they became proud owners of a new public area that they could take care of. During the workshops they were encouraged to talk about the area needs, construct models and make good choices, which gradually lead to concrete formal decisions. The intervention included the collaboration of local artisans and businesses that sourced the necessary materials and showed the young the way to initiate other processes in turn and source the materials themselves.

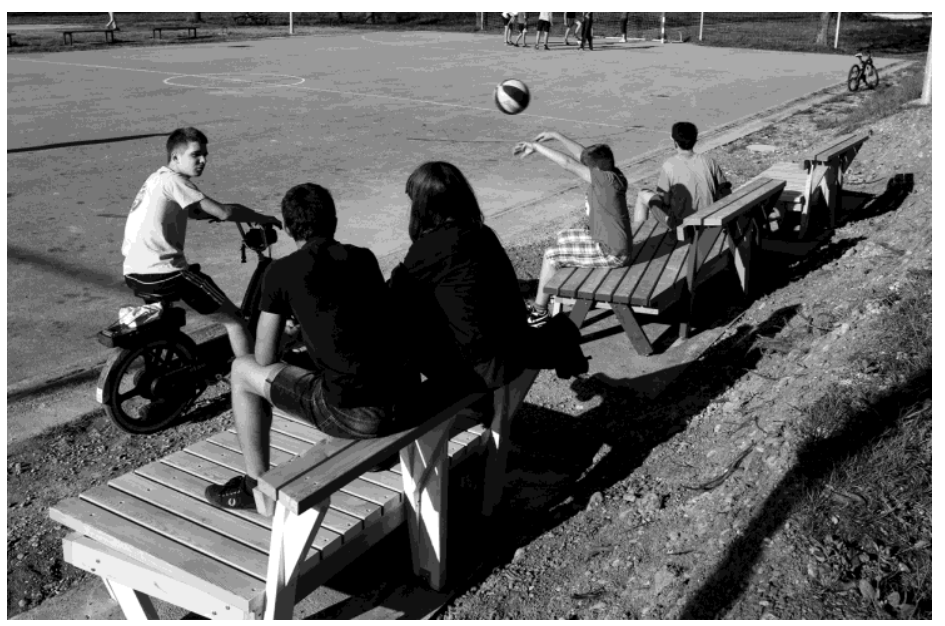

Figure 8: Urban Acupuncture - The Meeting Stripe (photo: Domen Grögl).

The fifth urban acupuncture intervention in Zalog took place between January and April 2013. Organization Womenspace executed the intervention in different public spaces; asking different questions about the relationship of women towards public space in Zalog (Figure 9). Within a series of workshops, women of different ages and backgrounds talked about their involvement in public space, their experiences, and the accommodations they need and wish for in public space. The workshop coordinators assembled their input in 
the form of stories, drawings, and maps into a mental map of the suburb. Such maps can serve as tools for improvement of public space for women.

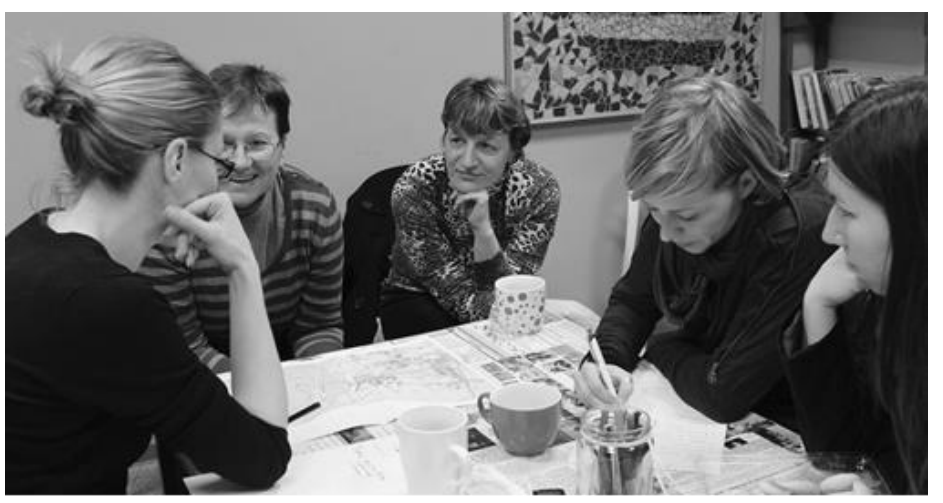

Figure 9: Urban Acupuncture Womenspace (photo: Domen Grögl).

Yet another activity was related to the local youth centre. It took place in the centre of the neighbourhood where a former neighbourhood community centre had been demolished to make room for a new commercial building. The construction of a new shopping mall on the site and the incompatibility of the programme forced the youth centre to move out and look for another seat. It is now located in the building previously used as a library, situated on the fringes of the neighbourhood.

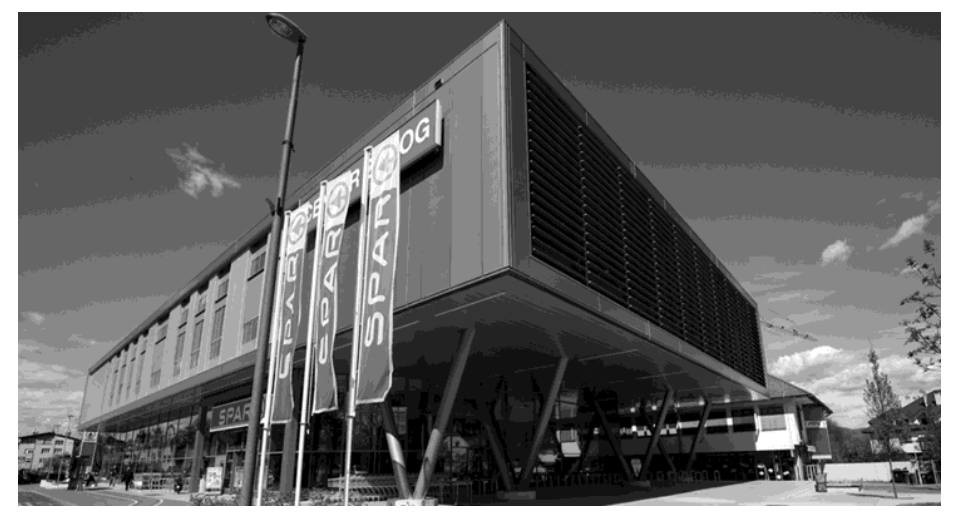

Figure 10: The new commercial building in Zalog in oversized format (photo: Domen Grögl).

For a better understanding of how urban acupuncture affected the Zalog community, the neighbourhood, and public space, we summarize the most important results in Table 1. The communication development, impact on public space, and investment of residents have been mapped and evaluated. 
Table 1: Urban acupuncture in Zalog and its impact on the community (2011 - 2013).

\begin{tabular}{|c|c|c|c|}
\hline & $\begin{array}{l}\text { Communication } \\
\text { development }\end{array}$ & $\begin{array}{l}\text { Impact on public } \\
\text { space }\end{array}$ & $\begin{array}{l}\text { Involvement of local } \\
\text { residents }\end{array}$ \\
\hline Down by the Water & $\begin{array}{l}\text { Excellent: } \\
\text { connection of youth } \\
\text { centre and } \\
\text { stakeholders }\end{array}$ & $\begin{array}{l}\text { Excellent: } \\
\text { reconstruction of the } \\
\text { playground }\end{array}$ & $\begin{array}{l}\text { Youth, age } 11-25 \\
\text { Elderly, age } 60-70\end{array}$ \\
\hline Design Your City & $\begin{array}{l}\text { Very good: } \\
\text { connection of youth } \\
\text { centre, stakeholders } \\
\text { and international } \\
\text { institutions }\end{array}$ & $\begin{array}{l}\text { Very good: definition } \\
\text { of dangerous spaces } \\
\text { and spaces related to } \\
\text { identity of the } \\
\text { neighbourhood }\end{array}$ & Youth, age $15-20$ \\
\hline Conversations & $\begin{array}{l}\text { Very good: } \\
\text { connection of youth } \\
\text { centre and primary } \\
\text { school }\end{array}$ & $\begin{array}{l}\text { Good: educational } \\
\text { impact }\end{array}$ & Children, age 8-11 \\
\hline The Meeting Stripe & $\begin{array}{l}\text { Excellent: } \\
\text { connection of youth } \\
\text { centre, primary } \\
\text { school, and local } \\
\text { stakeholders- } \\
\text { craftsmen }\end{array}$ & $\begin{array}{l}\text { Excellent: definition } \\
\text { of the meeting point } \\
\text { for dwellers }\end{array}$ & Teenagers, age $11-18$ \\
\hline Womenspace & $\begin{array}{l}\text { Excellent: } \\
\text { connection of youth } \\
\text { centre with local } \\
\text { activists }\end{array}$ & $\begin{array}{l}\text { Excellent: definition } \\
\text { of safe spaces for } \\
\text { women in the } \\
\text { neighbourhood }\end{array}$ & Women, age $10-60$ \\
\hline
\end{tabular}

\section{Conclusion}

The nature and dynamics of urban sprawl in Central Europe take on different dimensions: infrastructure-related sprawl can be observed around Athens (Salvati \& Zitti, 2017); postsocialist city sprawl is taking place in Warsaw and Ljubljana; sprawl based on second homes can be encountered in Austria (Couch, 2008). Many needs of Central European suburban residents, ranging from infrastructural to cultural and communal, remain unfulfilled. "To start with, a unique yet common relation with their living environment would be needed to define in a steady way the notion of 'home'. Some qualities of these undefined, transitional landscapes should be discovered, and reformulated to give a new sense of place to these often non-places. The traditional urban planning policies will not work here. The efforts to tie these areas to the cities are too big and expensive to be feasible; while the population migrating to the suburbs will probably create new ones if these areas will become neatly urban" (Kádár, 2012). Development of neighbourhoods in post-transition Eastern European countries is strongly influenced by neoliberal distribution of capital. Investor urbanism disregards content diversity and promotes oneway communication of interests from the political elite and capital investors to the developers. Combatting investor urbanism is not constructive; rather, we should work towards improving the communication within the community, and thus create a selfsufficient micro urbanism. There is a necessity for civil society organizations to amplify the voices of the community, lobby against investor urbanism interests, and counteract some of its destructive effects. 
The article presents urban acupuncture, a bottom-up method of urban intervention that represents an alternative to profit-driven, investor urbanism projects. The concept of urban acupuncture is an alternative form of small-scale "place-making" that is based on human relations and prioritizes public interest. Urban acupuncture influences community building by providing the residents with a sense of common ownership of a particular space and promotes the use of this space to express and reinforce local identity. An important aspect of community building is enforcing the discussion and creating concrete urban actions in neglected spaces. Using urban acupuncture at the level of a neighbourhood enables resistance to capital investments and relies on emotional investment of residents of neglected areas into public space. Resilience projects are based on community needs; they simultaneously create new forms of active participation and open possibilities for intergenerational collaboration in the neighbourhood. The diverse contents included in the Zalog urban acupuncture implementation clearly show that it is possible to build a community and develop intergenerational relations but only over a longer period of time, and with experts working in close association with the community. The open public space of the Zalog playground is an example par excellence of the potential of such interventions - it transformed a neglected and dangerous space into a neighbourhood community meeting point.

Boštjan Bugarič, University of Ljubljana, Faculty of Architecture, Ljubljana, Slovenia (bostjan@architectuul.com)

\section{Acknowledgments}

The research presented in this paper was performed in the scope of the research project Culburb, financed by the Education and Culture DG - Culture Programme with the support of the European Commission, the Visegrad Fund, the European Cultural Foundation, the Ministry of Culture of the Czech Republic, the Ministry of Culture of the Slovak Republic, the Ministry of Culture of the Republic of Slovenia, the Ministry of Culture and National Heritage of the Republic of Poland, the Municipality of Ljubljana, the Municipality of Prague, the Municipality of Warsaw, the Municipality of Bratislava, the Municipality of Budapest, the Municipality of Vienna, MC Gallery New York, UNAM Mexico City, the Austrian Culture Forum, Kiberpipa Ljubljana, and MSUM+ Modern Art Museum in Ljubljana.

\section{References}

Berényi, E. (2013) Suburbanization patterns around post socialist Budapest. Available at: http://www.culburb.eu/research/suburbanization-patterns-around-post-socialist-budapest/ (accessed 12 June 2016).

Bugarič, B. (2010) Otok na robu Istre. Dialogi, 46(7/8), pp. 72-83.

Chamberlain, L. (2017) Richard Florida and the new urban crisis; The common edge podcast. Available at: http://commonedge.org/the-common-edge-podcast-richard-florida-and-the-new-urban-crisis/ (accessed 25 Apr. 2017).

Couch, C., Petschel-Held, G., Leontidou, L. (2008) Urban sprawl in Europe: Landscape, land-use change and policy. Oxford, Wiley-Blackwell.

Centre for Central European Architecture (2012) Cultural acupuncture treatment for suburbs (CULBURB). Available at: http://www.culburb.eu/ (accessed 12 Maj 2013).

Czepczyński, M. (2008) Cultural landscapes of post-socialist cities: Representation of powers and needs. London, Ashgate.

Džokić, A., Neelen, M. \& Bugarič, B. (2011) This place exists only while we are here. Ljubljana, Rotterdam, STEALTH.unlimited \& KUD C3.

Florida, R. (2003) The rise of the creative class: And how it's transforming work, leisure, community, and 
everyday life. Cambridge, Taschenbuch.

Gruber, S. (2012) Three theorems of acupuncture urbanism: Strategies for the suburbs. Typescript. Available at: http://www.culburb.eu/research/three-theorems-of-acupuncture-urbanism-strategiesfor-the-suburbs/ (accessed 12 Apr. 2017).

Harvey, D. (1978) The urban process under capitalism: A framework for analysis. International Journal of Urban and Regional Research, 2 (1-4), pp. 101-131. DOI: 10.1111/j.1468-2427.1978.tb00738.x

Harvey, D. (2008) The right to the city. New Left Review, 53, pp. 23-40.

Kádár, B. (2012) Suburban realities; Thoughts on the socio-physical development of Central European suburban landscapes. Available at: http://www.culburb.eu/research/suburban-realities-thoughts-onthe-socio-physical-development-of-central-european-suburban-landscapes-/ (accessed 22 July 2013).

Patel, B. (2015) Contemporary urban sociology. Available at: https://rampages.us/patelbv2/2015/10/04/chapter-4-contemporary-urban-sociology/ (accessed 25 Dec. 2017).

Riegler, J. (2013) Competitiveness vs. social balance: Gentrification as urban policy in cases in Budapest and Vienna. Available at: http://www.culburb.eu/soubory/research/j-riegler-gentr-as-urbanpolicy.pdf (accessed 22 Nov. 2017)

Salvati, L. \& Zitti, M. (2017) Sprawl and mega-events: Economic growth and recent urban expansion in a city losing its competitive edge (Athens, Greece). Urbani izziv, 28(2), pp.110-122. DOI: 10.5379/urbani-izziv-en-2017-28-02-003

Schmoch, M. (2017) From place-making to place-keeping? Urban Act - Driving Change for Better cities. Available at: http://www.blog.urbact.eu/2017/11/from-place-making-to-place-keeping/ (accessed 28 Dec. 2017).

Smith, N. (2002) New globalism, New urbanism: Gentrification as global urban strategy. Antipode, 34(3), pp. 427-450, DOI: $10.1111 / 1467-8330.00249$

Vilenica, A., Sekulić, D. \& Čukić, I. (2015) Stop investitorskom urbanizmu - Report from Belgrade waterfront. dérive - Zeitschrift fur Stadtforschung, 59.

Vives Miró, S. (2011) Producing a "successful city": Neoliberal urbanism and gentrification in the tourist city-The case of Palma (Majorca). Urban Studies Research, 2011, pp. 1-13.

DOI: $10.1155 / 2011 / 989676$

Whyte, W. H. (2001) The social life of small urban spaces. New York, Project for Public Spaces. 